\title{
Towards a deterministic sustainable cost-effective water supply chain
}

\author{
Hassan Rezazadeh ${ }^{\mathbf{a}^{*}}$ and Zahra Tahmasebi ${ }^{\mathrm{a}}$
}

\begin{abstract}
${ }^{a}$ Department of Industrial Engineering, Faulty of Mechanical Engineering, University of Tabriz, Tabriz, Iran
A B S T R A C T

Managing water resources is one of the most challenging problems in today's world. There is an immense change in climate change, population growth, and environment, thereby increasing pressures on water resources. Due to future uncertainty and availability of resources, many priorities should be taken into account in the drinking-water system such as environmental impacts, distribution costs and fixed costs. This paper proposes a deterministic mixed-integer linear programming (MILP) model for planning and designing a water supply chain network in order to optimize multi-objective problems. The model considers costs which include fixed and variable costs, in addition, it considers sustainability in terms of environmental viewpoint. The applicability of the model is appraised through a case study whose data gathered from related articles and water and waste company reports in Iran, which consists of five candidate reservoir nodes and four dam nodes besides eleven candidate locations for treatment plants. Thereafter, the proposed model has been coded in GAMS ${ }^{\circledR}$ optimization software. The model could be an expedient tool in order to manage urban water supply chains in a cost-effective and sustainable manner to satisfy water demand at every time period.
\end{abstract}

\section{Introduction}

Water and sanitation-related issues are the most pressing issue of our world. Extreme water shortage as a consequence of population increase, climatic change and diminishing the availability of freshwater in urbanized areas has led to limited access to clean drinking water. Water resources are unevenly distributed which aggravate water supply management concerns. Water decision makers now encounter challenges including water scarcity, financial concerns and growing water demand which makes water management increasingly important. This is being made even more challenging by climate change. Hence, Sustainable growth draws a great deal of interest from researchers. On the other hand, the other difficulty faced by this system bears on management of water treatment plants with the purpose of promoting a sustainable supply chain to ameliorate the environmental health and quality of life which is a vital factor to living in today's turbulent today world. It is imperative to maintain balance between water demand and environmental issues. Accordingly, designing a mathematical modeling considering minimizing cost and maximizing sustainability would be a salutary idea. Without improving water management, urban water demand will rise, water supply will decrease and population pressure will ruin infrastructure (Zarghami et al., 2008). Optimum water allocation from a river with reservoirs to multiple users of different locations characterized by demands which vary in time is a long term research and operational challenge (Veintimilla-Reyes et al., 2016). Several studies have been developed on optimization of water supply systems and promoting sustainability. Aforementioned literature has used mathematical modeling in order to satisfy demands and optimize the total costs and water allocation. To minimize the total cost of the drinking water supply, a mixed-integer nonlinear programming (MINLP) model was developed by Burgschweiger et al. (2009). Samani and Zanganeh (2010) developed a mixed-integer real linear programing to minimize the total cost in the water distribution system. In their study, optimization analysis is accomplished

* Corresponding author

E-mail address: hrezazadeh@tabrizu.ac.ir (H. Rezazadeh)

C 2021 by the authors; licensee Growing Science.

doi: $10.5267 /$ j.uscm.2021.5.006 
by using mixed-integer real linear programming which is linked through an iterative procedure to gain the optimal design. Verleye and Aghezzaf (2011) proposed an operational planning model minimizing production and distribution costs in large drinking water networks by using a commercial solver, BONMIN, in order to solve the problem heuristically. VeintimillaReyes et al. (2016) presented an NFO-LP model whose objective is to optimize the assigning of the water and location of reservoirs. The result of this model was useful to specify the single or multiple optimal reservoirs from a candidate set as well as to maximize demand satisfaction. Roozbahani et al. (2015) introduced a mathematical model to allocate water resources and maximize the profit of stakeholders of a shared watershed. In addition, they took into account the environmental water satisfaction over the entire basins which created a sustainable water allocation of a multi-stakeholder river basin. Fattahi and Fayyaz (2010) used a mathematical model using compromise programming to optimize multiobjective problems for urban water management. In this model, three objectives including water distribution cost, leakage water and social satisfaction level are considered. Nápoles-Rivera et al. (2015) proposed a mathematical model with the purpose of maximizing revenue from water sale and maintaining sustainability in terms of economic and environmental viewpoints under uncertainty. Shibu and Reddy (2014) in their study optimized design of water distribution networks (WDN) under demand uncertainty to minimize the cost of the network and provide higher reliability by using cross entropy. The uncertain demands were represented as FRVs, and used to assess the system performance in terms of fuzzy random system reliability of WDNs. Zhu et al. (2015) developed a model integrating agricultural and urban water management decisions in a two-stage stochastic optimization which includes water transfers, coordinating detailed water supply and demand building upon supply reliability and economic values of water. In order to minimize overall costs, a robust optimization (RO) approach and a two-stage stochastic programming was proposed by Ghelichi et al. (2017). They presented a water distribution network (WDS) in order to distinguish potable from the non-potable water supply through an integrated network. Saif and Al-mansoori (2014) presented a mixed-integer linear programing model for water supply chain aiming at minimizing the net present value of supply chain network, optimizing capacity expansion of facilities and optimizing the water production and transportation. Koleva et al. (2018) implemented a spatially-explicit multi-period Mixed Integer Linear Programming model which allows the design of water supply chains at regional and national scale to minimize the total cost. Their optimization model includes installation of new purification plants, capacity development and raw water trading schemes.

In addition, some researchers have developed mathematical programming models in order to design a sustainable water supply chain. "Sustainability" was defined as "meeting society's current needs without depriving the future generations from meeting their needs in any way" (UN, 1972). Ahn and Kang (2014) proposed a model which integrates a genetic algorithm with a linear programming model for sustainable long-term planning and management of water supply systems. This paper developed the model so as to minimize operation costs and meet demand requirements and satisfy operational constraints. A decision-making support system was presented by García-Cáceres et al. (2019) in order to reach an optimal planning of a treatment plant in the line of having sustainable manufacturing practices. Their mathematical model consists of bi-objective function including maximizing the profit and minimizing the emission of pollutants. Pulluru and Akkerman (2016) developed a mathematical programming so as to integrate water reuse and regeneration in a relatively efficient manner to promote sustainability. They developed a water-integrated scheduling approach based on mathematical programming to capture the main characteristics of water flows in batch process plants.

In this paper, we present MILP deterministic mathematical modeling of multi-period multi-echelon sustainable closed loop supply chain for designing urban water supply chain in order to make decisions in the line of determining facility location and water allocation as well as minimizing the emission of pollutants in water treatment stages in four time periods. In the current model, permeation of water is taken into account. In addition, a practical example is presented to illustrate the impact of the model. on the water supply chain. In fact, this model intends to find a lower-cost and sustainable approach for grounding the infrastructures and transferring cost as well as minimization of the negative effects of pollutants emission.

\section{Problem description}

This paper presents a multi-period closed loop water supply chain considering total cost and sustainability for urban water supply systems, thereby motivating by gaps in literature (Fig. 1). As shown in Fig. 1 the first level includes the water resources, including surface water, and wells and dams. The next step is the process of treatment wherein surface water of dams and groundwater of wells are transferred to treatment plants separately to their own special treatments in order to purify for urban water consumption. Also, leakage as one of the components of water loss is considered to examine the realworld activity. After refinement, both kinds of water are transported to the reservoirs to satisfy the water demands. The closed loop part of the proposed model enables the system to return the collected waste waters of consuming zones to the waste water treatments aiming at minimizing the contaminants during the water refining process which makes the system's suitability. The final level contains the transferring filtered water from wastewater treatment to the surface water in order to reuse it. 


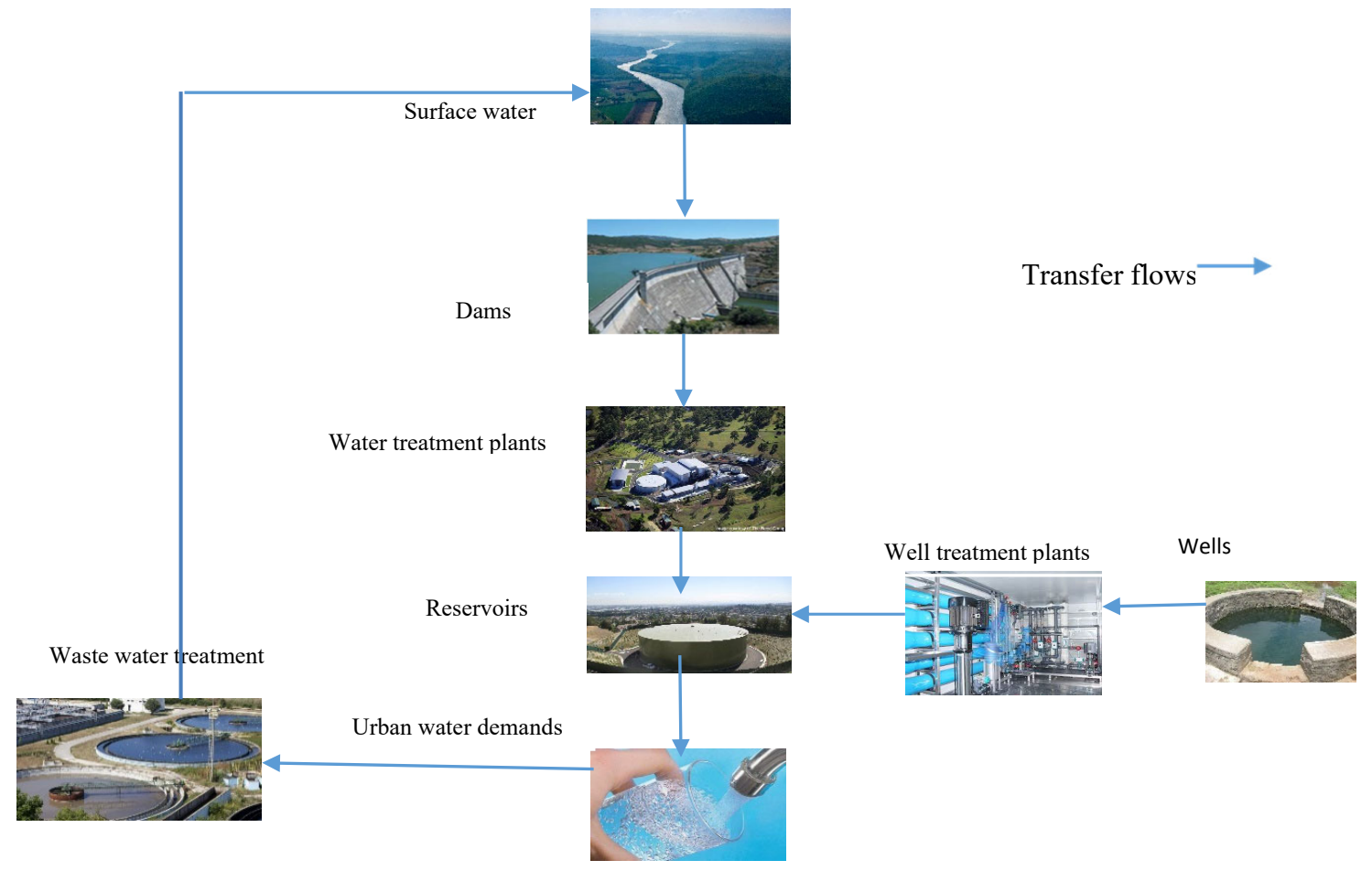

Fig. 1. Schematic presentation of the water supply chain

Some of the key questions in this water supply chain are: how much water must be provided during the different seasons of the year from each water resource? Which suggested location must be constructed in terms of cost and optimization policy? What is the optimal amount of distributed water to minimize the transferring cost and minimize the emission of pollutants while satisfying the demands? To answer these questions a deterministic multi-period multi-echelons closed loop water network is modeled in the first place. The aim of the proposed model includes finding cost-effective solutions for constructing and transferring plans, besides promoting sustainability throughout the urban water distribution system.

\section{Deterministic model}

A deterministic mathematical modeling is proposed which considers key aspects of supply chain including supply, planning and distribution. The set of dams and wells and surface water constitute the first line of water supply chain that provide network water resources, the set of treatments, reservoirs' demand represent the next echelons. The model establishes where these facilities must be built or chosen, besides it determines amount of transported water between locations in each time period $(t \in T)$ in terms of minimum amount of cost and pollutants.

\subsection{Mathematical modeling}

The indices, parameters, and decision variables of the proposed model are described in this section in Table 1-3 below.

\section{Table 1}

Sets

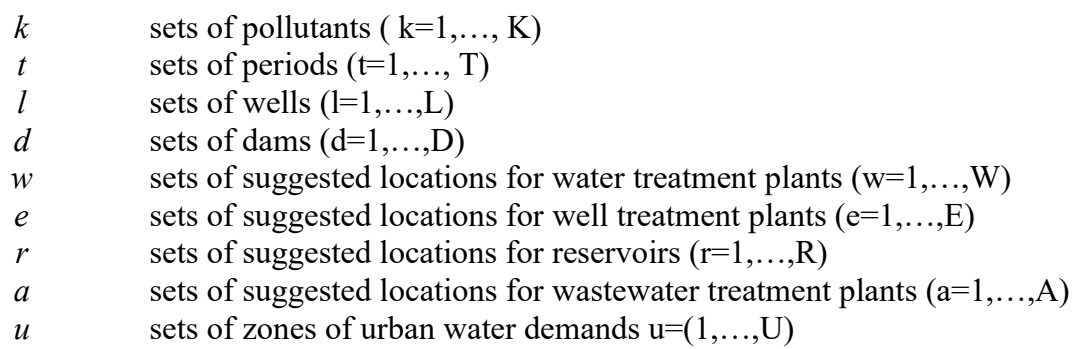

Table 2

Parameters

$H_{k t} \quad$ Maximum amount of type k pollutant allowed to produce in period $t$

$M_{\text {kat }} \quad$ Amount of pollutant $k$ produced per unit of water in wastewater treatment $a$ in period $t$ 
$C_{w} \quad$ Fixed cost of constructing water treatment plant in suggested location $w$

$C_{e} \quad$ Fixed cost of constructing well treatment plant in suggested location $e$

$C_{r} \quad$ Fixed cost of constructing reservoir in suggested location $r$

$C_{a} \quad$ Fixed cost of constructing wastewater treatment plant in suggested location $a$

$C_{d} \quad$ Fixed cost of selecting dam $d$

$C_{l} \quad$ Fixed cost of selecting well $l$

$T R_{d w t} \quad$ Transferring cost from location $d$ to $w$ per unit of water in period $t$

$T R_{w r t} \quad$ Transferring cost from location $w$ to $r$ per unit of water in period $t$

$T R_{\text {rut }} \quad$ Transferring cost from location $r$ to $u$ per unit of water in period $t$

$T R_{\text {let }} \quad$ Transferring cost from location $l$ to $e$ per unit of water in period $t$

$T R_{\text {ert }} \quad$ Transferring cost from location $e$ to $r$ per unit of water in period $t$

$T R_{\text {uat }} \quad$ Transferring cost from location $u$ to $a$ per unit of water in period $t$

$T R_{a t} \quad$ Transferring cost from location $a$ to surface water per unit of water in period $t$

$T R_{d t} \quad$ Transferring cost from surface water to dam $d$ per unit of water in period $t$

$L E_{d w t} \quad$ Amount of leakage water per unit from location $d$ to $w$ in period $t$

$L E_{w r t} \quad$ Amount of leakage water per unit from location $w$ to $r$ in period $t$

$L E_{\text {rut }} \quad$ Amount of leakage water per unit from location $r$ to $u$ in period $t$

$L E_{\text {let }} \quad$ Amount of leakage water per unit from location $l$ to $e$ in period $t$

$L E_{\text {ert }} \quad$ Amount of leakage water per unit from location $e$ to $r$ in period $t$

$L E_{\text {uat }} \quad$ Amount of leakage water per unit from location $u$ to $a$ in period $t$

$L E_{a t} \quad$ Amount of leakage water per unit from $a$ to surface water in period $t$

$D E_{u t} \quad$ Demand of customer $u$ for urban water in period $t$

$M C_{w} \quad$ Maximum capacity of treatment plant in location $w$

$M C_{e} \quad$ Maximum capacity of treatment plant in location $e$

$M C_{r} \quad$ Maximum capacity of reservoir in location $r$

$M C_{a} \quad$ Maximum capacity of wastewater treatment plant in location $a$

$M C_{d} \quad$ Maximum capacity of dam $d$

$M C_{l} \quad$ Maximum capacity of well $l$ for water extraction

Table 3

Decision variables

$Y_{w} \quad$ Binary variable takes 1 if a water treatment plant is constructed at suggested location $w, 0$ otherwise

$Y_{r} \quad$ Binary variable takes 1 if a reservoir is constructed at suggested location $r, 0$ otherwise

$Y_{e} \quad$ Binary variable takes 1 if a well treatment plant is constructed at suggested location $e, 0$ otherwise

$Y_{d} \quad$ Binary variable takes 1 if dam $d$ is chosen to supply the water, 0 otherwise

$Y_{l} \quad$ Binary variable takes 1 if well $l$ is chosen to supply the water, 0 otherwise

$Y_{a} \quad$ Binary variable takes 1 if a wastewater treatment is constructed at suggested location $a, 0$ otherwise

$X_{d w t} \quad$ Amount of water flow from suggested location $d$ to $w$ in period $t$

$X_{w r t} \quad$ Amount of water flow from suggested location $w$ to $r$ in period $t$

$X_{\text {rut }} \quad$ Amount of water flow from suggested location $r$ to customer $u$ in period $t$

$X_{\text {uat }} \quad$ Amount of wastewater flow from customer $u$ to suggested location $a$ in period $t$

$X_{\text {let }} \quad$ Amount of water flow from suggested location $l$ to $e$ in period $t$

$X_{\text {ert }} \quad$ Amount of water flow from suggested location $e$ to $r$ in period $t$

$X_{a t} \quad$ Amount of water flow from suggested location $a$ to surface water in period $t$

$X_{d t} \quad$ Amount of water flow from surface water to suggested location $d$ in period $t$

$I n v_{w t} \quad$ Water inventory in water treatment plant at location $w$ in period $t$

$I n v_{e t} \quad$ Water inventory in well treatment plant at location $e$ in period $t$

Inv $v_{a t} \quad$ Water inventory in wastewater treatment at location $a$ in period $t$

Inv $v_{r t} \quad$ Water inventory in reservoir at location $r$ in period $t$

Inv $v_{d t} \quad$ Water inventory in dam at location $d$ in period $t$

\subsection{Objective function}

The goal of this study is to reduce theoverall cost which are shown by $T C 1$ and TC2, including fixed and transition costs, besides minimizing the amount of the pollutants to reduce the environmentalimpact. TC illustrates the totalfixed cost of constructing or choosing the wells, dams, treatments, reservoirs. TC2 demonstrates the total value of transferring costs which includes the cost of transferring of water throughout the distribution network. Onthe other hand, Z2 shows the total emission of contaminantsthrough the water refinement in wastewater treatment plants. Two objective functions would be integrated by employing LP-metric method in GAMS with regardto the following constraints.

$$
\operatorname{Min} \mathrm{Z}_{1}=\mathrm{TC}_{1}+\mathrm{TC}_{2}
$$




$$
\begin{aligned}
& \mathrm{TC}_{1}=\sum_{\mathrm{w}=1}^{\mathrm{W}} \mathrm{C}_{\mathrm{w}} \mathrm{Y}_{\mathrm{w}}+\sum_{\mathrm{e}=1}^{\mathrm{E}} \mathrm{C}_{\mathrm{e}} \mathrm{Y}_{\mathrm{e}}+\sum_{\mathrm{r}=1}^{\mathrm{R}} \mathrm{C}_{\mathrm{r}} \mathrm{Y}_{\mathrm{r}}+\sum_{\mathrm{a}=1}^{\mathrm{A}} \mathrm{C}_{\mathrm{a}} \mathrm{Y}_{\mathrm{a}}+\sum_{\mathrm{d}=1}^{\mathrm{D}} \mathrm{C}_{\mathrm{d}} \mathrm{Y}_{\mathrm{d}}+\sum_{\mathrm{l}=1}^{\mathrm{L}} \mathrm{C}_{\mathrm{l}} \mathrm{Y}_{\mathrm{l}} \\
& \mathrm{TC}_{2}=\sum_{\mathrm{d}=1 \mathrm{w}=1 \mathrm{t}=1}^{\mathrm{D}} \sum^{\mathrm{W}} \mathrm{TR}_{\mathrm{dwt}} \mathrm{X}_{\mathrm{dwt}}+\sum_{\mathrm{w}=1}^{\mathrm{T}} \sum_{\mathrm{r}=1}^{\mathrm{R}} \sum_{\mathrm{t}=1}^{\mathrm{T}} \mathrm{TR}_{\mathrm{wrt}} \mathrm{X}_{\mathrm{wrt}}+\sum_{\mathrm{r}=1}^{\mathrm{R}} \sum_{\mathrm{u}=1}^{\mathrm{U}} \sum_{\mathrm{t}=1}^{\mathrm{T}} \mathrm{TR}_{\text {rut }} \mathrm{X}_{\text {rut }}+\sum_{\mathrm{u}=1}^{\mathrm{U}} \sum_{\mathrm{a}=1}^{\mathrm{A}} \sum_{\mathrm{t}=1}^{\mathrm{T}} \mathrm{TR}_{\text {uat }} \mathrm{X}_{\text {uat }} \\
& +\sum_{\mathrm{l}=1}^{\mathrm{L}} \sum_{\mathrm{e}=1}^{\mathrm{E}} \sum_{\mathrm{t}=1}^{\mathrm{T}} \mathrm{TR}_{\text {let }} \mathrm{X}_{\text {let }}+\sum_{\mathrm{e}=1}^{\mathrm{E}} \sum_{\mathrm{r}=1}^{\mathrm{R}} \sum_{\mathrm{t}=1}^{\mathrm{T}} \mathrm{TR}_{\text {ert }} \mathrm{X}_{\text {ert }}+\sum_{\mathrm{d}=1}^{\mathrm{D}} \sum_{\mathrm{t}=1}^{\mathrm{T}} \mathrm{TR}_{\mathrm{dt}} \mathrm{X}_{\mathrm{dt}}
\end{aligned}
$$$$
\operatorname{Min} \mathrm{Z}_{2}=\sum_{\mathrm{a}=1}^{\mathrm{A}} \sum_{\mathrm{k}=1}^{\mathrm{K}} \sum_{\mathrm{t}=1}^{\mathrm{T}} \sum_{\mathrm{u}=1}^{\mathrm{U}}\left(\mathrm{X}_{\text {uat }}-\mathrm{LE}_{\text {uat }} \mathrm{X}_{\text {uat }}\right) \mathrm{M}_{\mathrm{kat}}
$$

\subsection{Constraints}

Eq. (5) ensures that the water inventory level at the end of period $t$ in dam in location $d$ is equal to all transported water plus the inventory level at the end of period $t-1$, with subtracting the summation of water outflow in period $t$.

$$
\operatorname{InV}_{\mathrm{d}(\mathrm{t}-1)}-\sum_{\mathrm{w}=1}^{\mathrm{W}} \mathrm{X}_{\mathrm{dwt}}{ }^{+} \mathrm{X}_{\mathrm{dt}}=\operatorname{InV}_{\mathrm{dt}} \quad \forall \mathrm{t}, \mathrm{d}
$$

Eq. (6) ensures that the water inventory level at the end of period $t$ in every location $w$ is equal to all water inflow plus the inventory level at the end of period $t-1$, with subtracting the summation of water outflow in period $t$.

$$
\sum_{\mathrm{d}=1}^{\mathrm{D}}\left(\mathrm{X}_{\mathrm{dwt}}-\mathrm{LE}_{\mathrm{dwt}} \mathrm{X}_{\mathrm{dwt}}\right)+\operatorname{InV}_{\mathrm{w}(\mathrm{t}-1)}-\sum_{\mathrm{r}=1}^{\mathrm{R}} \mathrm{X}_{\mathrm{wrt}}=\operatorname{InV}_{\mathrm{wt}} \forall \mathrm{t}, \mathrm{w}
$$

Constraint (7) ensures that, the water inventory level at the end of the period $t$ in every location of $r$ should be equal to the Summation of the influx of water with subtracting the amount of the outflow of water in period $t$ plus the inventory level of period $t-1$.

$$
\sum_{\mathrm{e}=1}^{\mathrm{E}}\left(\mathrm{X}_{\mathrm{ert}}-\mathrm{LE}_{\mathrm{ert}} \mathrm{X}_{\mathrm{ert}}\right)+\operatorname{InV}_{\mathrm{r}(\mathrm{t}-1)}-\sum_{\mathrm{u}=1}^{\mathrm{U}} \mathrm{X}_{\mathrm{rut}}+\sum_{\mathrm{w}=1}^{\mathrm{w}}\left(\mathrm{X}_{\mathrm{wrt}}-\mathrm{LE}_{\mathrm{wrt}} \mathrm{X}_{\mathrm{wrt}}\right)=\operatorname{InV}_{\mathrm{rt}} \quad \forall \mathrm{t}, \mathrm{r}
$$

Eq. (8) is considered to satisfy the demands. All transferred potable water from reservoirs to consumer $u$ must be greater or equal to demand $u$ in period $t$.

$$
\sum_{\mathrm{r}=1}^{\mathrm{R}}\left(\mathrm{X}_{\mathrm{rut}}-\mathrm{X}_{\mathrm{rut}} \mathrm{LE}_{\mathrm{rut}}\right) \geq \mathrm{DE}_{\mathrm{ut}} \quad \forall \mathrm{u}, \mathrm{t}
$$

Eq. (9) ensures that the water inventory level from period $t-1$, plus the Inflow of water with the subtraction of the amount of the outflow of water of period $t$ must be equal the water inventory level at the end of the period $t$ in every location of $e$.

$$
\sum_{\mathrm{l}=1}^{\mathrm{L}}\left(\mathrm{X}_{\text {let }}-\mathrm{LE}_{\mathrm{let}} \mathrm{X}_{\text {let }}\right)+\operatorname{Inv}_{\mathrm{e}(\mathrm{t}-\mathrm{l})}-\sum_{\mathrm{r}=1}^{\mathrm{R}} \mathrm{X}_{\mathrm{ert}}=\operatorname{Inv}_{\mathrm{et}} \quad \forall \mathrm{t}, \mathrm{e}
$$

Eq. (10) ensures that the water inventory level at the end of period $t$ in every location $a$ is equal to all water inflow plus the inventory level at the end of period $t-1$, with subtracting the summation of water outflow in period $t$.

The overall amount of the pollutant $k$ produced in period $t$ must be equivalent to or less than the maximum level which is allowed to produce in period $t$, Eq. (11).

$$
\sum_{\mathrm{a}=1}^{\mathrm{A}} \sum_{\mathrm{u}=1}^{\mathrm{U}}\left(\mathrm{X}_{\text {uat }}-\mathrm{LE}_{\text {uat }} \mathrm{X}_{\text {uat }}\right) \mathrm{M}_{\mathrm{kat}} \leq \mathrm{H}_{\mathrm{kt}} \quad \forall \mathrm{t}, \mathrm{k}
$$

Constraint (12) ensures that, the summation of water inflow in period $t$ plus the inventory level of period $t-1$ does not exceed the maximum capacity of well treatment plant $e$, if it is constructed. 


$$
\sum_{\mathrm{l}=1}^{\mathrm{L}}\left(\mathrm{X}_{\mathrm{let}}-\mathrm{LE}_{\mathrm{let}} \mathrm{X}_{\mathrm{let}}\right)+\operatorname{InV}_{\mathrm{e}(\mathrm{t}-\mathrm{l})} \leq \mathrm{MC}_{\mathrm{e}} \mathrm{Y}_{\mathrm{e}} \quad \forall \mathrm{t}, \mathrm{e}
$$

In the same manner, the summation of water inflow in period $t$, plus the water inventory level in period $t-1$ must be equal or less than the maximum capacity of plant $w$, if it is constructed.

$$
\sum_{\mathrm{d}=1}^{\mathrm{D}}\left(\mathrm{X}_{\mathrm{dwt}}-\mathrm{LE}_{\mathrm{dwt}} \mathrm{X}_{\mathrm{dwt}}{ }^{)}+\operatorname{InV}_{\mathrm{w}(\mathrm{t}-1)} \leq \mathrm{MC}_{\mathrm{w}} \mathrm{Y}_{\mathrm{w}} \quad \forall \mathrm{t}, \mathrm{w}\right.
$$

Constraint (14) ensures that, the summation of water inflow in period $t$, plus the inventory level of period $t$ - 1 does not exceed the maximum capacity of reservoir $r$, if it is constructed.

$$
\sum_{\mathrm{e}=1}^{\mathrm{E}}\left(\mathrm{X}_{\mathrm{ert}}-\mathrm{LE}_{\mathrm{ert}} \mathrm{X}_{\mathrm{ert}}\right)^{+}+\operatorname{InV}_{\mathrm{r}(\mathrm{t}-1)}+\sum_{\mathrm{w}=1}^{\mathrm{w}}\left(\mathrm{X}_{\mathrm{wrt}}-\mathrm{LE}_{\mathrm{wrt}} \mathrm{X}_{\mathrm{wrt}}\right) \leq \mathrm{MC}_{\mathrm{r}} \mathrm{Y}_{\mathrm{r}} \quad \forall \mathrm{t}, \mathrm{r}
$$

The amount of water inflow, plus the inventory level from previous period in period $t$ must be less than or equal to maximum capacity of plant $a$, if it is constructed.

$$
\sum_{\mathrm{u}=1}^{\mathrm{U}}\left(\mathrm{X}_{\text {uat }}-\mathrm{LE}_{\text {uat }} \mathrm{X}_{\text {uat }}\right)+\operatorname{InV}_{\mathrm{a}(\mathrm{t}-\mathrm{l})} \leq \mathrm{MC}_{\mathrm{a}} \mathrm{Y}_{\mathrm{a}} \quad \forall \mathrm{a}, \mathrm{t}
$$

The summation amount of water outflow in period $t$ must be less than the maximum capacity of the well in location $l$, if it selected.

$$
\sum_{\mathrm{e}=1}^{\mathrm{E}} \mathrm{X}_{\text {let }} \leq \mathrm{MC}_{1} \mathrm{Y}_{1} \quad \forall \mathrm{t}, 1
$$

Constraint (17) ensures that the amount of water inflow from surface water in period $t$ plus the inventory level of period $t$ 1 , must be less than the maximum capacity of dam in location $d$, if it is selected.

$$
\mathrm{X}_{\mathrm{dt}}+\operatorname{Inv}_{\mathrm{d}(\mathrm{t}-1)} \leq \mathrm{MC}_{\mathrm{d}} \mathrm{Y}_{\mathrm{d}} \quad \forall \mathrm{t}, \mathrm{d}
$$

Summation of water outflow from all consuming zones is equal to whole demands.

$$
\begin{aligned}
& \sum_{\mathrm{a}=1}^{\mathrm{A}} \sum_{\mathrm{u}=1}^{\mathrm{U}} \mathrm{X}_{\mathrm{uat}}=\sum_{\mathrm{u}=1}^{\mathrm{U}} \mathrm{DE}_{\mathrm{UT}} \quad \forall \mathrm{t} \\
& Y_{w}, Y_{r}, Y_{e}, Y_{d}, Y_{l}, Y_{a} \in\{0,1\} \\
& \text { All continuous variables } \geq 0
\end{aligned}
$$

\section{Case study}

The proposed model of this study is applied to design a deterministic sustainable cost-effective water supply chain in four time periods. Essential information is gathered according to data gathered approximately from articles and water and waste water company reports in Iran.

Table 4

Number of candidate locations of facilities model

Number of
nominated locations for wells

nor

dams

Number of
nominated
locations for water
treatment plants

Number of nominated

locations for well

treatment plants

$\begin{array}{ll}\text { Number of } & \text { Number of } \\ \text { nominated } & \text { nominated } \\ \text { locations for } & \text { locations for } \\ \text { reservoirs } & \text { wastewater }\end{array}$

treatment plants 
The number of nominations of facilities' locations are shown in Table 4. Furthermore, each facility which includes treatment plants, reservoirs, dams, wells contains certain capacity for storage of water. The available capacity for some treatments is presented in Table 5 and 6.

Table 5

Available capacity for nominated treatments and reservoirs construction

\begin{tabular}{cccc}
\hline Water treatment type & Capacity $\left(\times \mathbf{1 0}^{\mathbf{3}} \mathbf{m}^{\mathbf{3}}\right)$ & Reservoir type & Capacity $\left(\times \mathbf{1 0}^{\mathbf{3}} \mathbf{~ m}^{\mathbf{3}}\right)$ \\
\hline $\mathrm{w}_{1}$ & 250 & $\mathrm{r}_{1}$ & 70 \\
$\mathrm{w}_{2}$ & 400 & $\mathrm{r}_{2}$ & 100 \\
$\mathrm{~W}_{3}$ & 300 & $\mathrm{r}_{3}$ & 150 \\
$\mathrm{w}_{4}$ & 350 & $\mathrm{r}_{4}$ & 210 \\
$\mathrm{w}_{5}$ & 200 & $\mathrm{r}_{5}$ & 300 \\
\hline
\end{tabular}

Table 6

Available capacity for candidate dams and treatments construction

\begin{tabular}{cccccc}
\hline Dam type & Capacity $\left(\times \mathbf{1 0}^{\mathbf{3}} \mathbf{m}^{\mathbf{3}}\right)$ & $\begin{array}{c}\text { Well } \\
\text { type }\end{array}$ & treatment & Capacity $\left(\times \mathbf{1 0}^{\mathbf{3}} \mathbf{m}^{\mathbf{3}}\right)$ & $\begin{array}{l}\text { Wastewater } \\
\text { treatment type }\end{array}$ \\
\hline $\mathrm{d}_{1}$ & 1100 & $\mathrm{e}_{1}$ & 100 & $\mathrm{a}_{1}$ & $\left.\mathrm{Capacity} \times \mathbf{1 0}^{\mathbf{3}} \mathbf{m}^{\mathbf{3}}\right)$ \\
$\mathrm{d}_{2}$ & 900 & $\mathrm{e}_{2}$ & 110 & 150 \\
$\mathrm{~d}_{3}$ & 1500 & $\mathrm{e}_{3}$ & 250 & 210 & $\mathrm{a}_{2}$ \\
\hline
\end{tabular}

The leakage rate and transfer cost for each time period is variable based on the weather specifications. Some of this information is presented in Table 7. In addition, the water demand for each consuming area is specified. The reason why urban water demand is variable in each time period is due to the weather characteristics. The consuming needs for each area for four time periods are presented in Table 8.

Table 7

Leakage rate and transfer cost for each route and for each time period

\begin{tabular}{|c|c|c|c|c|}
\hline Path type & $\begin{array}{l}\text { Transfer cost (Rial) per } \\
\text { unit }\left(1 \mathrm{~m}^{3}\right) \text { in } t_{1} / \text { leakage } \\
\text { rate } \%\end{array}$ & $\begin{array}{l}\text { Transfer cost (Rial) per } \\
\text { unit }\left(1 \mathrm{~m}^{3}\right) \text { in } t_{2} \\
\text { /leakage rate } \% \\
\end{array}$ & $\begin{array}{l}\text { Transfer cost (Rial) per } \\
\text { unit }\left(1 \mathrm{~m}^{3}\right) \text { in } t_{3} \\
\text { /leakage rate } \% \\
\end{array}$ & $\begin{array}{l}\text { Transfer cost (Rial) per } \\
\text { unit }\left(1 \mathrm{~m}^{3}\right) \text { in } t_{4} \\
\text { leakage rate } \%\end{array}$ \\
\hline $\mathrm{e}_{1}, \mathrm{r}_{1}$ & $100 / 0.01$ & $200 / 0.09$ & $190 / 0.07$ & $225 / 0.08$ \\
\hline $\mathrm{e}_{1}, \mathrm{r}_{2}$ & $290 / 0.1$ & $230 / 0.05$ & $435 / 0.06$ & $221 / 0.08$ \\
\hline $\mathrm{e}_{1}, \mathrm{r}_{3}$ & $180 / 0.07$ & $200 / 0.35$ & $350 / 0.03$ & $285 / 0.07$ \\
\hline $\mathrm{e}_{1}, \mathrm{r}_{4}$ & $220 / 0.02$ & $250 / 0.03$ & $150 / 0.15$ & $510 / 0.05$ \\
\hline $\mathrm{e}_{1}, \mathrm{r}_{5}$ & $221 / 0.05$ & $150 / 0.08$ & $220 / 0.03$ & $230 / 0.07$ \\
\hline $\mathrm{e}_{2}, \mathrm{r}_{1}$ & $290 / 0.04$ & $290 / 0.11$ & $410 / 0.07$ & $200 / 0.03$ \\
\hline $\mathrm{e}_{2}, \mathrm{r}_{2}$ & $430 / 0.06$ & $230 / 0.08$ & $230 / 0.17$ & $290 / 0.04$ \\
\hline $\mathrm{e}_{2}, \mathrm{r}_{3}$ & $350 / 0.07$ & $600 / 0.11$ & $290 / 0.04$ & $220 / 0.13$ \\
\hline $\mathrm{e}_{2} \cdot \mathrm{r}_{4}$ & $290 / 0.07$ & $510 / 0.08$ & $360 / 0.05$ & $285 / 0.11$ \\
\hline $\mathrm{e}_{2}, \mathrm{r}_{5}$ & $150 / 0.04$ & $610 / 0.06$ & $225 / 0.05$ & $220 / 0.07$ \\
\hline $\mathrm{e}_{3}, \mathrm{r}_{1}$ & $221 / 0.08$ & $290 / 0.09$ & $350 / 0.07$ & $200 / 0.05$ \\
\hline $\mathrm{e}_{3}, \mathrm{r}_{2}$ & $100 / 0.01$ & $230 / 0.18$ & $430 / 0.06$ & $250 / 0.30$ \\
\hline $\mathrm{e}_{3}, \mathrm{r}_{3}$ & $310 / 0.03$ & $150 / 0.07$ & $500 / 0.21$ & $410 / 0.04$ \\
\hline $\mathrm{e}_{3 .} \mathrm{r}_{4}$ & $220 / 0.04$ & $185 / 0.15$ & $285 / 0.09$ & $100 / 0.02$ \\
\hline $\mathrm{e}_{3}, \mathrm{r}_{5}$ & $221 / 0.31$ & $200 / 0.07$ & $221 / 0.09$ & $510 / 0.07$ \\
\hline
\end{tabular}

Table 8

Consuming zones demand for each time period

\begin{tabular}{|c|c|c|c|c|}
\hline zone & $\begin{array}{c}\text { Demand in } t_{1} \\
\left(\times 10^{3} \mathrm{~m}^{3}\right)\end{array}$ & $\begin{array}{c}\text { Demand in } t_{2} \\
\left(\times 10^{3} \mathrm{~m}^{3}\right)\end{array}$ & $\begin{array}{c}\text { Demand in } t_{3} \\
\left(\times 10^{3} \mathrm{~m}^{3}\right)\end{array}$ & $\begin{array}{c}\text { Demand in } t_{4} \\
\left(\times 10^{3} \mathrm{~m}^{3}\right)\end{array}$ \\
\hline $\mathrm{u}_{1}$ & 578.1 & 520.02 & 532.48 & 520.02 \\
\hline $\mathrm{u}_{2}$ & 425.97 & 410.7 & 415.8 & 410.7 \\
\hline $\mathrm{u}_{3}$ & 908.58 & 883.8 & 890.2 & 883.2 \\
\hline $\mathrm{u}_{4}$ & 142.39 & 135.8 & 136.3 & 135.8 \\
\hline $\mathrm{u}_{5}$ & 207.97 & 201.10 & 204.43 & 201.8 \\
\hline
\end{tabular}

Environmental effect of wastewater treatment including the amount of produced pollutants per unit of water in each plant is shown in Table 9. Through the sewage treatment, which is the process of extracting the contaminants from wastewater to produce liquid in order to reuse, some pollutants are released. Three contaminants are considered in this part which should be minimized with the purpose of reducing the environmental negative impact. In the aforementioned model, GAMS ${ }^{\circledR}$ optimization program has been coded. Because of the models' MILP structure, CPLEX solver is used to solve the problem. The LP-metric method was used to solve the two-objective problem. This method is based on the concept of minimizing the digression between objective functions and their ideal solution obtained by individual optimization methods. 
The objectives values and other computational results including optimal amount of transferring water of the model are reported in Table which shows total cost of water supply chain along with total amount of produced pollutants during the refinement. In this way, managers of water resources would be able to investigate advantages and disadvantages of the proposed model. Fig. 2 depicts the distributed water from reservoirs to the demand zones over the four time periods. In addition, Fig. 3 demonstrates the distributed water from urban zones to wastewater treatment plants in order to reuse it through the purification procedure.

Table 9

Amount of producing pollutants for each wastewater treatment plan and each time period

\begin{tabular}{|c|c|c|c|c|}
\hline $\begin{array}{l}\text { wastewater treatment } \\
\text { and pollutant type }\end{array}$ & $\begin{array}{c}\text { Amount of produced } \\
\text { pollutant per unit of } \\
\text { water } \\
\left(\mathrm{g} / \mathrm{m}^{3}\right) \text { in } \mathrm{t}_{1}\end{array}$ & $\begin{array}{c}\text { Amount of produced } \\
\text { pollutant per unit of } \\
\text { water } \\
\left(\mathrm{g} / \mathrm{m}^{3}\right) \text { in } \mathrm{t}_{2}\end{array}$ & $\begin{array}{c}\text { Amount of produced } \\
\text { pollutant per unit of } \\
\text { water } \\
\left(\mathrm{g} / \mathrm{m}^{3}\right) \text { in } \mathrm{t}_{3}\end{array}$ & $\begin{array}{c}\text { Amount of produced } \\
\text { pollutant per unit of } \\
\text { water } \\
\left(\mathrm{g} / \mathrm{m}^{3}\right) \text { in } \mathrm{t}_{4}\end{array}$ \\
\hline $\mathrm{k}_{1} \cdot \mathrm{a}_{1}$ & 6 & 5 & 6 & 7 \\
\hline $\mathrm{k}_{1} \cdot \mathrm{a}_{2}$ & 5 & 6 & 3 & 4 \\
\hline $\mathrm{k}_{1} \cdot \mathrm{a}_{3}$ & 6 & 8 & 5 & 6 \\
\hline $\mathrm{k}_{2} \cdot \mathrm{a}_{1}$ & 3 & 5 & 6 & 8 \\
\hline $\mathrm{k}_{2} . \mathrm{a}_{2}$ & 6 & 4 & 6 & 5 \\
\hline $\mathrm{k}_{2} . \mathrm{a}_{3}$ & 6 & 5 & 3 & 4 \\
\hline $\mathrm{k}_{3} \cdot \mathrm{a}_{1}$ & 10 & 9 & 11 & 8 \\
\hline $\mathrm{k}_{3} . \mathrm{a}_{2}$ & 9 & 12 & 9 & 10 \\
\hline $\mathrm{k}_{3} . \mathrm{a}_{3}$ & 8 & 10 & 9 & 12 \\
\hline
\end{tabular}

Table 10

The results of proposed model

Model

Total cost (Rial)

total emission of contaminants (g)

Objective value

12202500000

147289700

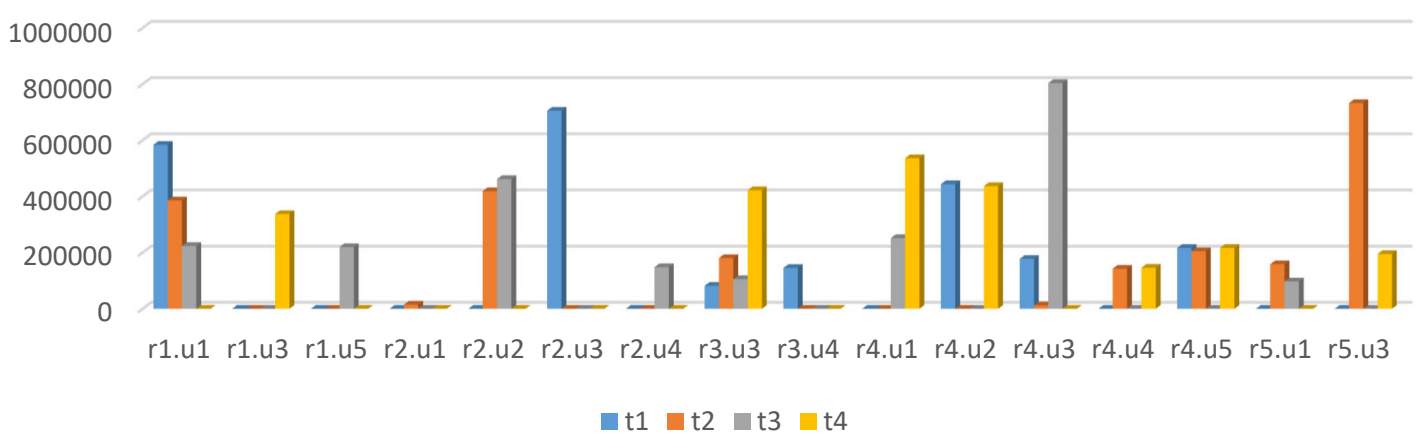

Fig. 2. $\mathrm{X}_{\mathrm{ru}}$ variable, amount of distributed water from reservoirs to the demand zones(results of the current model)

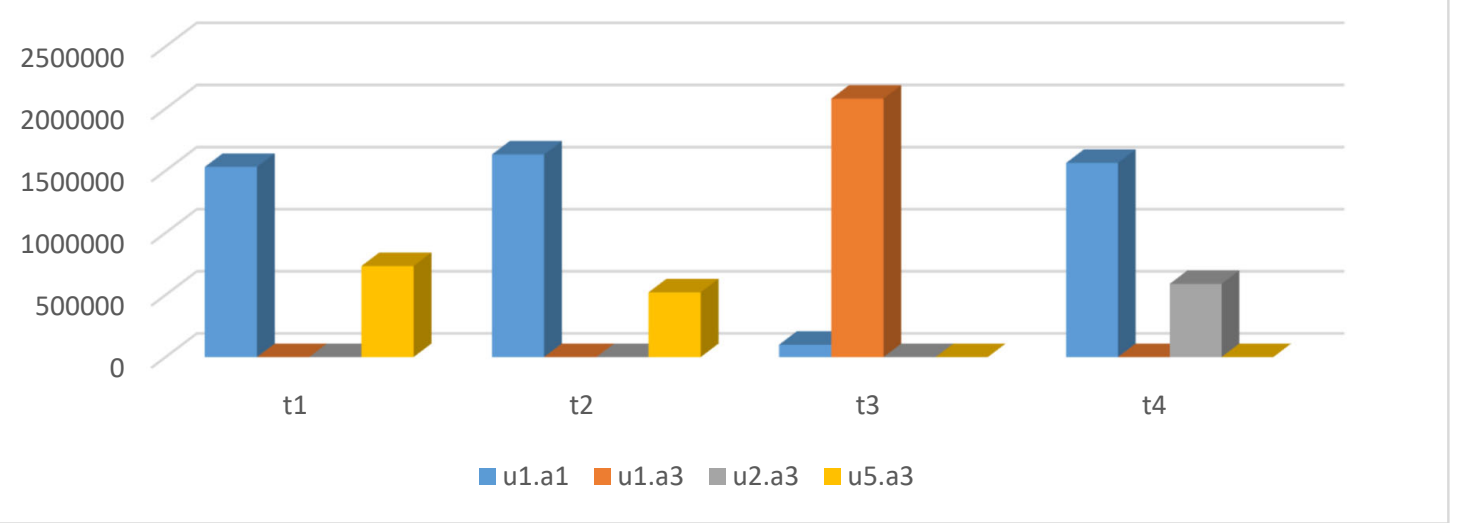

Fig. 3. $X_{\text {ua }}$ variable, amount of distributed water from urban zones to wastewater treatment plants 


\section{Conclusion}

One of the exigent issues in today's society is the shortage of water resources. Besides, getting polluted due to the population explosion exacerbates the issue. We need to preserve water resources for future generations. Therefore, many objectives should be considered in designing the water supply chain. This paper recommends a deterministic MILP mathematical programming model for designing a closed loop multi-echelon multi-period water supply chain for urban zones in order to minimize the overall cost and emission of pollutants.

The deterministic model has been developed under real assumptions in order to establish optimal design of the water network including determining the number of facilities and optimal amount of the distributed water.

The results of the model can help managers and policymakers to make suitable decisions about water supply chain network design which would be considered optimal allocation of water to consuming zones as well as planning on constructing the facilities according to cost-effective policy.

\section{References}

Ahn, J., \& Kang, D. (2014). Optimal planning of water supply system for long-term sustainability. Journal of HydroEnvironment Research, 8(4), 410-420.

Burgschweiger, J., Gnädig, B., \& Steinbach, M. C. (2009). Optimization models for operative planning in drinking water networks. Optimization and Engineering, 10(1), 43-73.

Fattahi, P., \& Fayyaz, S. (2010). A compromise programming model to integrated urban water management. Water Resources Management, 24(6), 1211-1227.

García-Cáceres, R. G., Castañeda-Galvis, M. T., \& Suárez-Fajardo, J. F. (2019). Towards an efficient and sustainable planning of the drinking water supply chain. Journal of Cleaner Production, 230, 394-401.

Ghelichi, Z., Tajik, J., \& Pishvaee, M. S. (2018). A novel robust optimization approach for an integrated municipal water distribution system design under uncertainty: A case study of Mashhad. Computers \& Chemical Engineering, 110, 1334.

Koleva, M. N., Calderón, A. J., Zhang, D., Styan, C. A., \& Papageorgiou, L. G. (2018). Integration of environmental aspects in modelling and optimisation of water supply chains. Science of The Total Environment, 636, 314-338.

Nápoles-Rivera, F., Rojas-Torres, M. G., Ponce-Ortega, J. M., Serna-González, M., \& El-Halwagi, M. M. (2015). Optimal design of macroscopic water networks under parametric uncertainty. Journal of Cleaner Production, 88, $172-184$. Pulluru, S. J., \& Akkerman, R. (2018). Water-integrated scheduling of batch process plants: Modelling approach and application in technology selection. European Journal of Operational Research, 269(1), 227-243.

Roozbahani, R., Abbasi, B., \& Schreider, S. (2015). Optimal allocation of water to competing stakeholders in a shared watershed. Annals of Operations Research, 229(1), 657-676.

Saif, Y., \& Almansoori, A. (2014). Design and operation of water desalination supply chain using mathematical modelling approach. Desalination, 351, 184-201.

Samani, H. M., \& Zanganeh, A. (2010, October). Optimisation of water networks using linear programming. In Proceedings of the Institution of Civil Engineers-water management (Vol. 163, No. 9, pp. 475-485). Thomas Telford Ltd.

Shibu, A., \& Reddy, M. J. (2014). Optimal design of water distribution networks considering fuzzy randomness of demands using cross entropy optimization. Water Resources Management, 28(12), 4075-4094.

Veintimilla-Reyes, J., Meyer, A. D., Cattrysse, D., \& Orshoven, J. V. (2018). From Linear Programming Model to Mixed Integer Linear Programming Model for the Simultaneous Optimisation of Water Allocation and Reservoir Location in River Systems. In Multidisciplinary Digital Publishing Institute Proceedings (Vol. 2, No. 11, p. 594).

Verleye, D., \& Aghezzaf, E. H. (2011, June). Modeling and optimization of production and distribution of drinking water at VMW. In International Conference on Network Optimization (pp. 315-326). Springer, Berlin, Heidelberg.

Zarghami, M., Abrishamchi, A., \& Ardakanian, R. (2008). Multi-criteria decision making for integrated urban water management. Water Resources Management, 22(8), 1017-1029.

Zhu, T., Marques, G. F., \& Lund, J. R. (2015). Hydroeconomic optimization of integrated water management and transfers under stochastic surface water supply. Water Resources Research, 51(5), 3568-3587. 
(C) 2021 by the authors; licensee Growing Science, Canada. This is an open access article distributed under the terms and conditions of the Creative Commons Attribution (CC-BY) license (http://creativecommons.org/licenses/by/4.0/). 